TP Periodica Polytechnica

61(2), pp. 322-334, 2017

https://doi.org/10.3311/PPci.9539

Creative Commons Attribution (i)

RESEARCH ARTICLE

\section{Effect of Rubber Tire Chips-Sand Mixtures on Performance of Geosynthetic Reinforced Earth Walls}

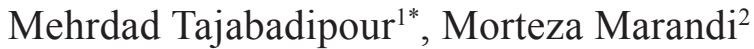

Received 30 May 2016; Revised 01 August 2016; Accepted 12 September 2016

\begin{abstract}
In recent years, lots of environmental problems have been created due to the advancement of technology and increasing the use of rubber material throughout the world as well as the lack of a correct and fundamental solution to rubber burial, recycling, and optimum use of it. In this paper, the performance of reinforced earth wall with geogrid and different percentages of crumb rubber-sand, as lightweight materials, have been evaluated and analyzed. In this regard, 20 types of embankment, formed by 4 layers of different material with a height of 2.5 meters, have been used. The results indicate that the mixture, with the ratio of 30:70 by weight or 50:50 by volume under the condition of applying surcharge load or even without it, was found to be the most suitable filler material compared to the other mixing ratios.
\end{abstract}

\section{Keywords}

reinforced earth walls, crumb rubber, geogrid, horizontal and vertical displacements, finite element

${ }^{1}$ Department of Civil engineering, Graduate University of Technology,

Kerman, Iran

${ }^{2}$ Department of Civil engineering ,Shahid Bahonar University of Kerman, Kerman, Iran

"Corresponding author email: mehrdad.tajabadipour@yahoo.com

\section{Introduction}

By the advancement of human societies and the increasing use of vehicles, millions rings of scrap tires around the world is taking out of the consumption cycle and collecting as garbage every year. Due to the high volume of scrap tires, dangerous fires occurrence, and the high cost of hygiene disposal, this issue has become one of the biggest environmental problems. Therefore, providing some solutions to this problem seems to be necessary. Some of the solutions are reusing them as filler materials in construction projects, such as road construction, retaining walls, and drainage systems. Over the past two decades, several studies have been conducted about the application of crumb rubber in the reinforcement of retaining earth walls and also about its use as filler materials in the road construction [1-3]. In addition to using crumb rubber in geotechnical projects, it is important to pay attention to possible environmental pollutions caused by these material types. For this reason, many experimental and field studies have been performed on the environments and fluids which are placed next to these materials. The obtained results show that no harmful effect is relevant and the only environmental limitation in the use of crumb rubber is related to their self-ignition potential [1-4]. In1998, the ASTM regulation provided the D6270 instruction to decrease this potential. Foose et al. (1996) investigated the behavior of sand reinforced by scrap tire chips with direct shear tests. The results of this research have illustrated that in all the cases, the addition of tire chips has caused an increase in the internal friction angle [5]. Lee et al (1999) investigated the use of tire chips as a light weight material. Triaxial test results and theoretical studies on the finite element method showed that there is a linear relationship between the deviator stress and axial strain of rubber components and chips [2]. Yoon et al (2004) studied bearing capacity and settlement of sand reinforced with crumb rubber by conducting plate load tests. The results of that research showed that the bearing capacity of the loose sand reinforced with scrap tire chips is 2 times more than the bearing capacity of loose sand. The settlement decrease caused by reinforcing the sand with the mixture of brick fragments and tire chips has been more than $70 \%$ for 
the loose sand and 34\% for the dense sand [6]. Youwai and Bergado(2004) used the numerical analysis of reinforced wall with tire chips and concluded that the total tensile force is normalized and wall lateral movement is increased by increasing the percentage of rubber chip mixture weight [7]. Gatland et al., (2005) conducted some studies on mixtures of crumb rubber-sand. Their research results showed that the percentage of crumb rubber has had a significant effect on the shear strength of the mixture of sand-crumb rubber [8]. Hataf and Rahimi (2005) investigated the use of scrap tire chips to increase bearing capacity with experimental models. Their results suggested that the addition of tire chips to sand would increase the C.B.R ratio from 1.17 to 3.9 [9]. Attom (2005) conducted some direct shear tests to investigate the effect of the addition of tire chips on the physical properties of sands, and the results suggested increased sand internal friction angle and shear strength [10]. Ghazavi and Amel Sakhi (2005) conducted researches on the effect of the rectangular rubber particles on the strength parameters of sandy soil. The results of direct shear test showed that there was only one specified length for a fixed width which provides the maximum angle of internal friction [11]. Raju and Prasad (2009) performed CBR tests on the mixtures of soil and the rubber powder, the highest resistance was reported at 6-8 volume percent [12]. Tanchausawat et al (2009) studied interaction between geogrid and crumb rubber-sand mixture to determine the characteristics of the sand backfill materials. The experimental results indicated that dry unit weight of crumb rubber - sand is more affected to the water content than that of the sand; and also the weight mixture by $30: 70$ or volume mixture by 50:50 is more appropriate than the other mixtures used in this way [13]. Balumaini et al (2009) investigated the interaction between the steel strip with crumb rubber-sand mixture. The results showed that the capacity of the steel strip pulled out in a mixture of crumb rubber-sand is more than in crumb rubber [14]. Nakhaee et al. (2011) studied the properties and dynamic behavior of soil-crumb rubber mixtures as well as the impact of their use on the retaining walls using large-scale triaxial tests and numerical analysis. Their research indicated that shear modulus are decreased for each limiting pressure along with an increase of tire. Also, a significant reduction was observed in the dynamic pressure and the residual displacement [15].

Historical studies show that the use of synthetic fill materials behind reinforced earth walls is one of things that have always been an interest of researchers. Despite the extensive theoretical and experimental studies, it seems that the use of recycled materials behind walls and influencing factors in the optimal design and implementation of these types of walls are among cases in need of more research. The current study investigated the performance of geogrid reinforced soil walls and the use of crumb rubber-sand as lightweight materials behind the wall.

\section{Material properties \\ 2.1 Backfill materials}

Filler material, precast concrete blocks, and geogrid material are used in this study. A new type of recyclable materials, which was used in reinforced earth walls, has been introduced in order to reduce the costs. New mixtures are composed of crumb rubber and Ayutthaya sand was used by Tanchaisawat et al. based on the conducted tests [13]. According to ASTM D854-97 and ASTM C127-0, specific gravities of sand and crumb rubber are respectively estimated 2.65 and 1.12 . These figures correspond to those suggested by Tanchaisawat et al. [12, 17, 18]. The percentage of particles passing sieve No. 200 was measured to be equal to $1.64 \%$ with $\mathrm{D}_{10}=22 \mathrm{~mm}, \mathrm{D}_{30}=0.38 \mathrm{~mm}$ and $\mathrm{D}_{60}=0.62$ with effective particle diameters. Coefficient uniformity $(\mathrm{Cu})$ and curvature coefficient $(\mathrm{Cc})$ were 2.82 and 1.06, respectively. According to the Unified Soil Classification System (USCS), sandy soil can be classified as poorly graded (SP) and the size of the most crumb rubber used have been in the range of 12 to $50 \mathrm{~mm}$ (Table 1).

Table 1 Index properties of Ayutthaya sand and tire chips [13].

\begin{tabular}{ccc}
\hline Property & Ayutthaya sand & Tire chip \\
\hline Specific gravity, Gs & 2.65 & 1.12 \\
Effective diameter, $\mathrm{D}_{10}(\mathrm{~mm})$ & 0.22 & 5.10 \\
Coefficient of uniformity, $(\mathrm{Cu})$ & 2.82 & - \\
Coefficient of curvature, $(\mathrm{Cc})$ & 1.06 & - \\
Classification (USCS) & $\mathrm{SP}$ & - \\
\hline
\end{tabular}

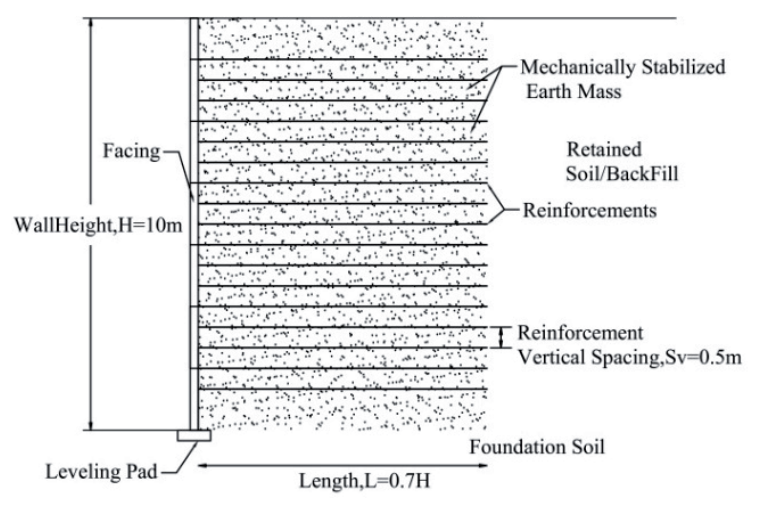

Fig. 1 Geometry of the modeled wall.

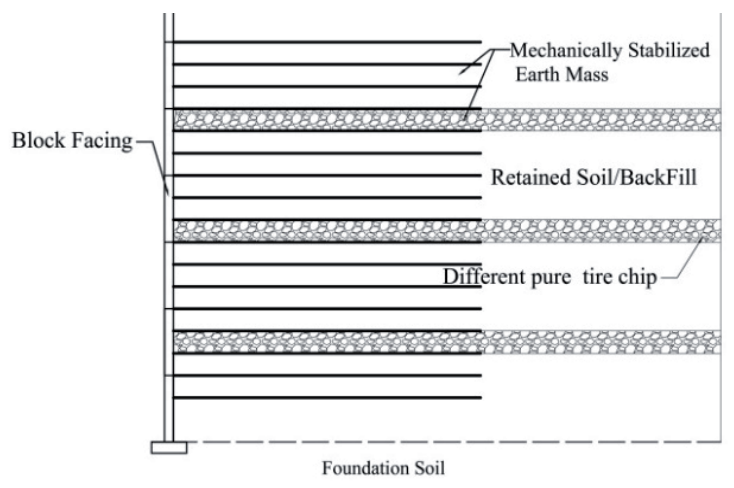

Fig. 2 Particle-size distribution of Ayutthaya sand and tire chips [13]. 
Table 2 Model parameters

\begin{tabular}{|c|c|c|c|c|c|c|}
\hline Mohr-Coulomb & Foundation Soil & loose Sand & Dense Sand & Silty Sand & Clayey Sand & Sand\& Gravel \\
\hline TYPE & Drained & Drained & Drained & Drained & Drained & Drained \\
\hline$\gamma_{\mathrm{d}}\left(\mathrm{kN} / \mathrm{m}^{3}\right)$ & 17 & 16 & 18 & 17.5 & 19 & 18 \\
\hline$\gamma_{\text {sat }}\left(\mathrm{kN} / \mathrm{m}^{3}\right)$ & 20 & 18 & 20 & 19 & 21 & 20 \\
\hline $\mathrm{K}_{\mathrm{x}}(\mathrm{m} / \mathrm{s})$ & $5.00 \mathrm{E}-04$ & $2.23 \mathrm{E}-03$ & $3.69 \mathrm{E}-01$ & $5.00 \mathrm{E}-06$ & $5.50 \mathrm{E}-06$ & $5.00 \mathrm{E}-06$ \\
\hline $\mathrm{K}_{\mathrm{y}}(\mathrm{m} / \mathrm{s})$ & $5.00 \mathrm{E}-04$ & 2.23E-03 & 3.69E-01 & $5.00 \mathrm{E}-06$ & $5.50 \mathrm{E}-06$ & $5.00 \mathrm{E}-06$ \\
\hline$v(-)$ & 0.3 & 0.25 & 0.35 & 0.35 & 0.3 & 0.35 \\
\hline $\mathrm{c}_{\mathrm{ref}}\left(\mathrm{kN} / \mathrm{m}^{2}\right)$ & 10 & 0 & 0 & 0 & 12 & 0 \\
\hline$\phi\left({ }^{\circ}\right)$ & 40 & 34 & 45 & 33 & 40 & 48 \\
\hline
\end{tabular}

Figure 2 represents the particle-size distribution curve of the sand and tire chips.

The crumb rubber-sand mixture used in this study are generally divided into 4 groups:

- (for crumb rubber) 0: 100 (for sand)

- $30: 70$

- $40: 60$

- $50: 50$

The first case in which the materials were used without crumb rubber was five types of sandy materials with different geotechnical characteristics (Table 2). Permeability of various types materials (Table 2) considered based on Swiss Standard SN 670 010b [33].

Table 3 shows the results of compression tests carried out for each material. Maximum dry density for crumb rubbersand mixture changes was between 9.5 and $13.5 \mathrm{kN} / \mathrm{m}^{3}$. The optimum moisture content also varies from 5.7 to $8.8 \%$ [13]. In this mixture, the amount of sand has had an effect on the mixture dry density, however the moisture content has not had any effects on the dry density. The homogenity of tire-sand mixtures performed based on mixing ratios of the tire chipsand mixtures. Table 4 indicates the shear strength parameters of crumb rubber-sand mixtures with different percentages obtained from pull out and large-scale direct shear tests.

The shear strength of material and geogrid components are increased as the amount of sand are increased due to the crumb rubber cavities being filled by sand. For vertical stresses and identical proportions, cohesion and friction angle are obtained less for each element of geogrid reinforcement material than filler materials. The friction angle and cohesion of backfills when use of geogrid B are obtained more than geogrid A.

In this study, crumb rubber was also used in the addition to the crumb rubber-sand mixtures. In this regard, the performance of crumb rubber with different sizes and shapes are discussed according to research and various tests which were carried out recently (Table 5).
Table 3 Compaction test results of tire chip-sand mixtures [13].

\begin{tabular}{ccc}
\hline $\begin{array}{c}\text { Mixing ratio of tire } \\
\text { chip:sand(\% by weight) }\end{array}$ & $\begin{array}{c}\text { Max. dry unit } \\
\text { weight }\left(\mathbf{k N} / \mathbf{m}^{3}\right)\end{array}$ & $\begin{array}{c}\text { Optimum moisture } \\
\text { content(\%) }\end{array}$ \\
\hline $0: 100$ & 18.71 & 12.5 \\
$30: 70$ & 13.60 & 8.8 \\
$40: 60$ & 11.90 & 7.1 \\
$50: 50$ & 9.50 & 5.7 \\
\hline
\end{tabular}

The interaction between the elements of reinforcement and materials has been considered based on experimental studies [13]. The geogrid interaction coefficients B estimated in direct shear and pull out tests were 0.93 and 0.74 , respectively. The geogrid interaction B was higher in the direct shear test due to the large size of the geogrid aperture, and in the pull out test, a lower interaction coefficient has been obtained due to the lower tensile strength. The geogrid interaction coefficient A with materials, obtained in both of the pull out tests in direct shear, was 0.87 (Table 6).

\subsection{Reinforcing material}

The two geogrid types selected in this research are based upon the reinforcement elements used in the pull out and direct shear tests (Tanchaisawat et al.). Geogrid A (Saint-Gobain DJG 120X120-1) consists of high tenacity woven polyester fibers existing in polymeric blend. Geogrid B (100/30 Polyfelt geogrid GX) consists of high strength polyester fibers. These fibers are woven in a stable network and protected by polymeric coating (Fig.3). Tensile strength of geogrid A was 120 $\mathrm{kN} / \mathrm{m}$ with strain at break $12.7 \%$, and the tensile strength of geogrid B was $100 \mathrm{kN} / \mathrm{m}$ with strain at break of $13.2 \%$. These values are not so different from those in the product specifications of their manufacturers [13].

The distance considered between the geogrids in all the models is $0.5 \mathrm{~m}$. The first and last reinforcement layers were placed $1 \mathrm{~m}$ from the bottom of the wall and the top of it. Different regulations have announced different minimum variable lengths of reinforcement for reinforced soil walls. In this study, the length $0.7 \mathrm{H}$ has been used according to the FHWA regulation [21]. 
Table 4 Shear strength parameters of tire chip-sand mixtures and with geogrid reinforcement [13]

\begin{tabular}{|c|c|c|c|c|c|c|c|c|c|c|}
\hline \multirow{2}{*}{$\begin{array}{l}\text { Mixing } \\
\text { ratio }\end{array}$} & \multicolumn{2}{|c|}{ Mixtures only } & \multicolumn{4}{|c|}{ With geogrid A } & \multicolumn{4}{|c|}{ With geogrid B } \\
\hline & $\begin{array}{l}\Phi \\
\left({ }^{\circ}\right)\end{array}$ & $\begin{array}{c}\mathrm{c} \\
(\mathrm{kPa})\end{array}$ & $\begin{array}{c}\delta \\
\left({ }^{\circ}\right)\end{array}$ & $\begin{array}{l}{ }^{*} \delta \\
\left({ }^{\circ}\right)\end{array}$ & $c_{i}(k P a)$ & $c_{i}^{*}(\mathrm{kPa})$ & $\begin{array}{c}\delta \\
\left({ }^{\circ}\right)\end{array}$ & $\begin{array}{c}{ }^{*} \delta \\
\left({ }^{\circ}\right)\end{array}$ & $c_{i}(\mathrm{kPa})$ & $c_{i}{ }^{*}(\mathrm{kPa})$ \\
\hline $30: 70$ & 26.31 & 15.50 & 21.25 & 24.22 & 13.50 & 12.80 & 20.96 & 25.80 & 10.00 & 13.50 \\
\hline $40: 60$ & 23.43 & 13.20 & 19.57 & 21.25 & 12.10 & 10.00 & 19.00 & 22.08 & 7.55 & 11.00 \\
\hline $50: 50$ & 18.43 & 12.90 & 17.57 & 17.86 & 11.00 & 9.80 & 16.58 & 18.15 & 6.90 & 10.00 \\
\hline
\end{tabular}

Note: $\delta$ denotes skin friction angle obtained from in-soil pull out tests. $\delta$ * denotes skin friction angle obtained from large-scale direct shear tests. $\mathrm{c}_{\mathrm{i}}$ denotes adhesion obtained from in-soil pull out tests. $\mathrm{c}_{\mathrm{i}} *$ denotes adhesion obtained from large-scale direct shear tests.

\subsection{Characteristics of precast concrete block}

The solid segmental blocks used in this numerical analyses were precast type of concrete blocks. The height of this block type is $1.2-1.8 \mathrm{~m}$ and its thickness is $0.18-0.3 \mathrm{~m}$. In this research, blocks with a height of $1.5 \mathrm{~m}$, thickness of 0.2 , axial stiffness $\mathrm{EA}=7.5^{*} 10^{6} \mathrm{kN}$ and bending stiffness $\mathrm{EI}=2.5^{*} 10^{4} \mathrm{kN}$. m have been used. Figure 1 shows the cross-sectional geometry of the models.

Table 5 Shear strength of different types of tire shreds

\begin{tabular}{ccccc}
\hline Author & $\begin{array}{c}\text { Maximum } \\
\text { Size }(\mathbf{m m})\end{array}$ & $\begin{array}{c}\text { Unit weight } \\
\left(\mathbf{k N} / \mathbf{m}^{3}\right)\end{array}$ & $\begin{array}{c}\mathbf{C} \\
\left(\mathbf{k N} / \mathbf{m}^{2}\right)\end{array}$ & $\begin{array}{c}\mathbf{\Phi} \\
\mathbf{(})\end{array}$ \\
\hline Humphrey & 76 & 6.13 & 11.5 & 19 \\
(1993) & 51 & 6.3 & 7.7 & 21 \\
Ahmed (1993) & 13 & 6.19 & 22.7 & 11.2 \\
Yang (2002) & 25 & 6.32 & 25.4 & 12.6 \\
Gotteland (2005) & $\begin{array}{c}\text { circular } \\
\text { chips }\end{array}$ & 6.1 & 1.6 & 11 \\
\hline
\end{tabular}

Table 6 Interaction coefficients of geogrid reinforcements

\begin{tabular}{cccc}
\hline $\begin{array}{c}\text { Mixing Ratio Tire } \\
\text { Chip:Sand }\end{array}$ & $\begin{array}{c}\text { GA(R }{ }_{\text {in }}{ }^{*} \text { pull out } \\
\text { \& Full scale } \\
\text { shear test) }\end{array}$ & $\begin{array}{c}\text { GB } \\
\mathbf{R}_{\text {in }} \text { (pull } \\
\text { out) }\end{array}$ & $\begin{array}{c}\text { GB R }_{\text {in }} \text { (Full } \\
\text { scale shear test) }\end{array}$ \\
\hline $30: 70$ & 0.87 & 0.74 & 0.93 \\
$40: 60$ & 0.87 & 0.74 & 0.93 \\
$50: 50$ & 0.87 & 0.74 & 0.93 \\
\hline
\end{tabular}

Note: $\mathrm{R}_{\mathrm{in}}{ }^{\text {}}$ denotes Interaction Coefficient

The walls were considered with the same height $\mathrm{H}=10 \mathrm{~m}$ in modeling system. In all models, static analysis was done without the surcharge load and underground water level at the bottom of the wall.

\section{Numerical modeling}

Numerical modeling is one of the effective tools to further understand the behavior of different structures, and using this type of modeling, it is possible to observe changes created in stress, strain, displacement and etc,in different structure points. The PLAXIS software has been used for modeling. The real position can be modeled using plane strain or axial symmetry models. This software can consider the two model types of plane strain and axial symmetry. Also, it is possible to use different models of soil behavior such as linear elastic, Mohr Coulomb, hardening soft soil and soft soil creep models [16]. In the present research, for higher accuracy in the measurement of the stresses and strains, the 15-node element has been used.

The height of the panel wall $(\mathrm{H}=10 \mathrm{~m})$ and depth of toe embedment $(\mathrm{D}=50 \mathrm{~cm})$. The width of the numerical model was selected to concurrently optimize computation time and minimize the influence of problem boundaries. The length of the reinforcement elements was taken as $\mathrm{L}=0.7 \mathrm{H}(7 \mathrm{~m})$, which is a typical recommended minimum value in design codes (FHWA). The wall facing was modeled as discrete Panels of $1.5 \mathrm{~m}$ height with a horizontal joint thickness of $20 \mathrm{~mm}$. The panels and joints (bearing pads) were modeled using linear elastic beam elements.in this study the width of materials in the back of wall and depth of foundation is considered $25,10 \mathrm{~m}$, respectively.

When the geometry model is fully defined and material properties are assigned to all clusters and structural objects, the geometry has to be divided into finite elements in order to perform finite element calculations. A composition of finite elements is called a mesh.in this investigation the basic type of element in a mesh is the 15-node triangular element and in fine mesh.

\section{Problem layout}

One of the most important elements in reinforced soil walls are backfill materials. In most cases, granular fill materials are used, but the important point beside their geotechnical advantages is their price. Therefore, it is necessary to use recyclable materials and study about their effects on the performance of this type of wall. To study the effect of using crumb rubber and also its different mixtures with sand as light materials in reinforced soil walls with finite element method (FEM) has been employed to analyze some walls. For this purpose, along with using the results of the two full scale tests of pull out and direct shear, the mixtures of crumb rubber-sand with the weight percentage of 30:70 (sand), 40:60 and 50:50 (crumb rubber) have been used.

In this regard, five soil types (Table 2 ) with various granulation and sizes have been employed for evaluating the performance of the wall compared to the case in which mixtures of crumb rubber-sand have been used. For the simultaneous effect of geogrid tensile strength and soil type, two geogrid types with the mentioned properties have been applied. 
The wall performance has been accurately assessed when using different percentages of crumb rubber with other sand materials both after construction state and while applying different surcharge. Despite all the efforts that researchers have put into studying the performance of reinforced soil walls, it seems that the use of combined back wall materials, and with formed layers of different materials have been studied less. Therefore, 20 types of backfills with different properties (Table 7) have been used in a layer with a height of $2.5 \mathrm{~m}$ (Fig. 4). The effect of using crumb rubber-sand mixture in the wall foundations in layers with 0.5 and $1 \mathrm{~m}$ heights has been studied (Fig. 6). To evaluate the effect of soil type used in wall foundation, while using crumb layers, a 1 meter crumb rubber layer with a weight percentage of 30:70 and different geotechnical materials, whose properties are given by different researchers, have been used (Tables 8, 9 and 10).

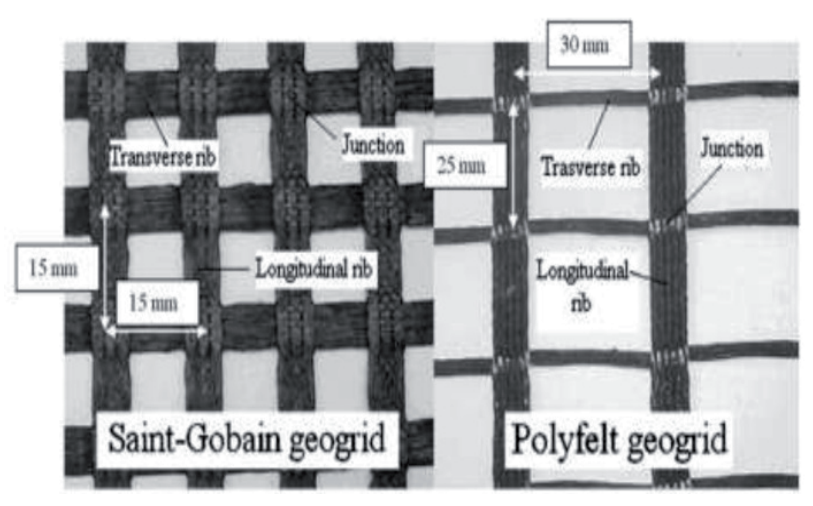

Fig. 3 Junction patterns of Saint-Gobain (geogrid A) and Polyfelt (geogrid B) [13]

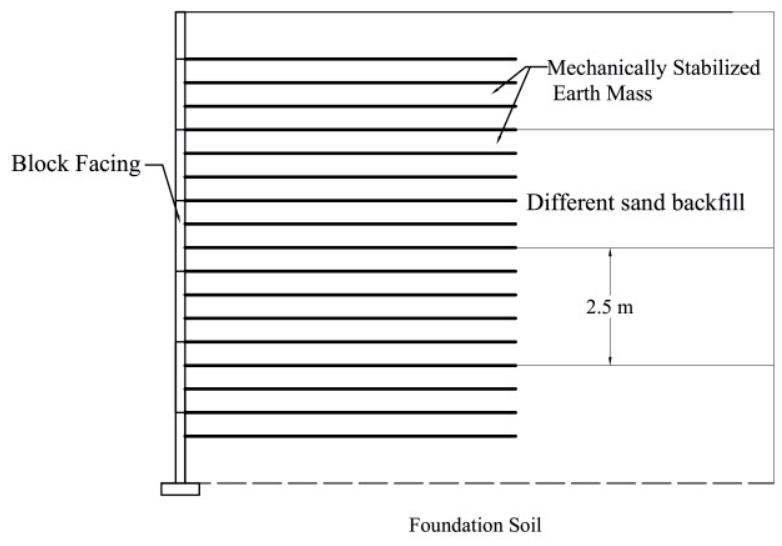

Fig. 4 Use of backfill materials in different layers

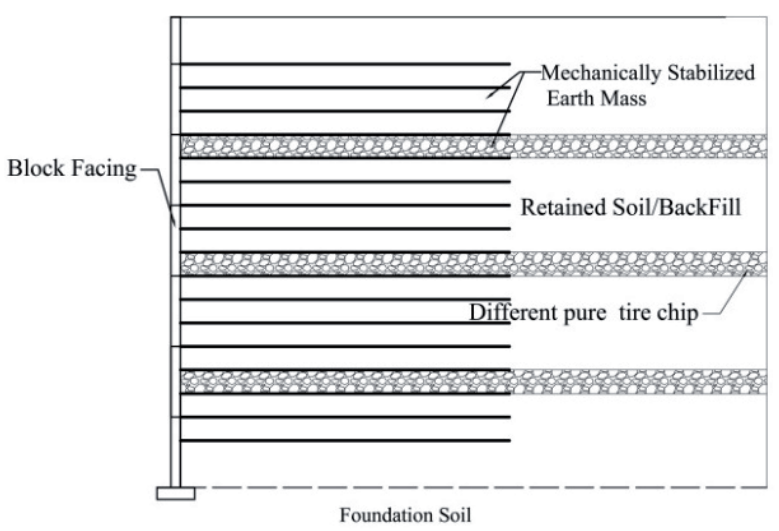

Fig. 5 Use of crumb rubber with different maximum size

Table 7 Different layer back fill

\begin{tabular}{lcccc}
\hline & Layer1 & Layer2 & Layer3 & Layer4 \\
\hline Embankment 1 & Ayutthaya sand & $30: 70 *$ & $50: 50$ & $50: 50$ \\
Embankment 2 & $30: 70$ & Ayutthaya sand & $40: 60$ & $30: 70$ \\
Embankment 3 & $40: 60$ & $50: 50$ & Ayutthaya sand & Ayutthaya sand \\
Embankment 4 & $50: 50$ & $40: 60$ & $30: 70$ & $50: 60$ \\
Embankment 5 & Dense Sand & $30: 70$ & $50: 50$ & $50: 50$ \\
Embankment 6 & $30: 70$ & Dense Sand & Dense Sand & Dense Sand \\
Embankment 7 & $40: 60$ & $50: 50$ & $30: 70$ & $50: 50$ \\
Embankment 8 & $50: 50$ & $40: 60$ & $40: 60$ & $40: 60$ \\
Embankment 9 & Sand \& Gravel & $30: 70$ & $50: 50$ & $30: 70$ \\
Embankment 10 & $30: 70$ & Sand \& Gravel & Sand \& Gravel \\
Embankment 11 & $40: 60$ & $50: 50$ & $30: 70$ & $40: 60$ \\
Embankment 12 & $50: 50$ & $40: 60$ & $50: 50$ & $50: 50$ \\
Embankment 13 & Clayey Sand & $30: 70$ & $40: 60$ & $30: 70$ \\
Embankment 14 & $30: 70$ & Clayey Sand & Clayey Sand \\
Embankment 15 & $40: 60$ & $50: 50$ & $30: 70$ & Clayey Sand \\
Embankment 16 & $50: 50$ & $40: 60$ & $30: 70$ & $40: 60$ \\
Embankment 17 & Sand \& Gravel & Dense Sand & Sand \& Gravel \\
Embankment 18 & Dense Sand & $30: 70$ & Dense Sand & Dense Sand \\
Embankment 19 & $30: 70$ & $40: 60$ & & $30: 70$ \\
Embankment 20 & $40: 60$ & Sand \& Gravel & & \\
\hline
\end{tabular}

Note:* Mixing ratio of tire chip:sand (\% by weight) 
Table 8 Properties of Granular Materials [22].

\begin{tabular}{|c|c|c|c|c|c|}
\hline Reference & Material & Test method $^{\mathrm{a}}$ & $\begin{array}{l}\text { D10 } \\
(\mathrm{mm})\end{array}$ & $\begin{array}{l}\text { Maximum dry unit weight } \\
\qquad\left(\mathrm{kN} / \mathrm{m}^{3)}\right.\end{array}$ & $\begin{array}{l}\text { Reported friction } \\
\text { angle }\end{array}$ \\
\hline Nash (1953) & Closely graded river sand & DS & 0.14 & 16.1 & 36.5 \\
\hline Kirkpatrick (1965) & Leighton buzzard sand & $\mathrm{TC}$ & 0.37 & 17.5 & 40.5 \\
\hline Lee and Seed (1967) & Sacramento river sand & $\mathrm{TC}$ & 0.14 & 16.3 & 39 \\
\hline Koerner (1970) & Crushed Ottawa sand & $\mathrm{TC}$ & 0.25 & 16.3 & 40.3 \\
\hline Holubec and Appolonia (1973) & Ottawa sand & $\mathrm{TC}$ & 0.15 & 17.6 & 35 \\
\hline Zelasko et al. (1975) & Ottawa $35-45$ & $\mathrm{TC}$ & 0.37 & 17.7 & 39.1 \\
\hline Salgado et al. (2000) & Ottawa sand (ASTM C778) & $\mathrm{TC}$ & 0.28 & 17.6 & 35.9 \\
\hline Simoni and Houlsby (2006) & Leighton buzzard sand & DS & 0.21 & 18.8 & 45 \\
\hline Cerato and Lutenegger (2006) & Brown mortar & DS & 0.3 & 16.7 & 48.3 \\
\hline
\end{tabular}

${ }^{\mathrm{a}} \mathrm{DS}=$ Direct shear and $\mathrm{TC}=$ triaxial compression.

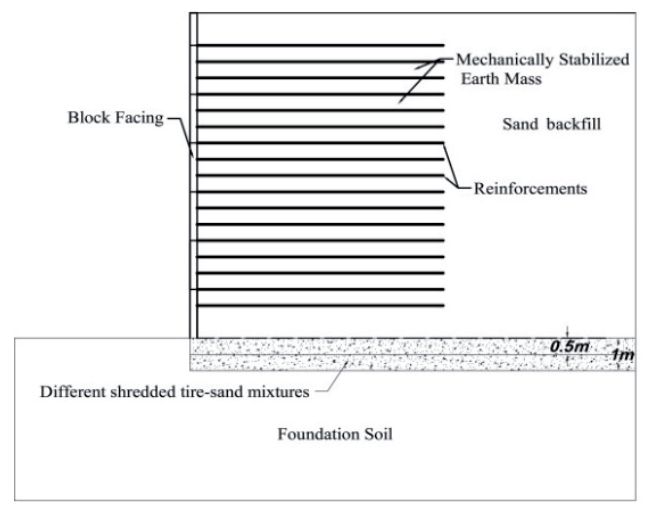

Fig. 6 Use of crumb rubber in the foundation of wall

Table 9 Properties of clayey sand

\begin{tabular}{cccc}
\hline Material & $\begin{array}{c}\text { Maximum dry } \\
\text { unit weight } \\
\left(\mathbf{k N / \mathbf { m } ^ { 3 } )}\right.\end{array}$ & $\begin{array}{c}\text { Friction angle } \\
\left({ }^{\circ}\right)\end{array}$ & $\begin{array}{c}\text { Cohesion } \\
\left(\mathbf{k N} / \mathbf{m}^{\mathbf{2}}\right)\end{array}$ \\
\hline Clayey Sand No.1 & 19 & 40 & 2 \\
Clayey Sand No.2 & 19 & 40 & 4 \\
Clayey Sand No.3 & 19 & 40 & 6 \\
Clayey Sand No.4 & 19 & 40 & 8 \\
Clayey Sand No.5 & 19 & 40 & 10 \\
\hline
\end{tabular}

\section{Results and discussion}

\subsection{Effect of different percentage of tire chips- sand mixture in performance of wall}

Figure 7 shows the normalized graph of the maximum horizontal displacement $\left(\delta_{\text {hmax }} / \mathrm{H}(\%)\right)$ for different percentages of crumb rubber-sand mixtures and other sand materials. The results indicate that the increase of crumb rubber proportion in mixture with sand increases the horizontal displacement of wall. Therefore, the increase in the percentage of crumb rubber or the decrease of sand in the mixture of crumb rubber-sand increases the maximum horizontal displacement of the wall.

The present results have a conformity with the past numerical studies [13].
Figure 8 shows the normalized graph of maximum settlement $\left(\delta_{v \max } / \mathrm{H}(\%)\right)$ for different soils. The increase in the percentage of the crumb rubber does not cause significant change in the settlement degree. When the mixture of crumb rubbersand is used, the strength of the geogrids is not so effective in the maximum settlement, and with the increase of the quantity of crumb rubber to $50 \%$, it has had the same result for both of the geogrids. Concerning to other sands, the geogrid strength has a higher effect on the maximum quantity of the settlement, and for dense and cohesive soils, this effect is less. Generally, the use of the crumb rubber-sand mixture has a very desirable effect compared to the other materials on the maximum quantity of the settlement degree. The pull out of reinforcement elements and the parameters of materials shear strength are the effective factors in the maximum displacement of reinforced soil walls. Therefore, in this research, the results from full scale pull out and direct shear tests (Tanchausawat et al. (2009)) have been used. The results of the pull out test show that the quantity of the sand in the mixture of rubber-sand is directly influence in the pull out strength due to the higher internal friction angle of sand over the crumb rubber. The 30:70 mixture with a lower percentage of crumb rubber than other percentages used in the mixtures, has a higher pull out strength (Fig. 9).

The 30:70 percent has a higher special weight compared to the other materials (Table 3). The results from the full scale direct shear test suggest that the increase in the percentage of crumb rubber in the mixture of crumb rubber-sand decreased the maximum shear strength (Fig. 9). The 30:70 percent used in the wall also has the lowest horizontal displacement compared to the other percentages used, and the results finely have a conformity with the experimental studies. Also, the increase in the density and cohesion of the soil decreased the maximum horizontal displacement of the wall. When clayed sand or dense sand is used, the tensile strength of the geogrids has a lower effect on the performance of the wall, and this effect tangibly is increased in the other sands along with the increase of crumb rubber.

The studies performed on different percentages of crumb rubber in the previous section covered the issues for the time 
after the construction which has been finished without applying surcharge. Figures 11 and 12 show the effect of surcharge on the maximum horizontal displacement and settlement for different percentages of crumb rubber-sand and different surcharge. The increase of surcharge has involved the increase of the horizontal and vertical displacement of wall for all the materials. Of course, the increasing trend caused by the surcharge in the mixture of sand and gravel for the maximum horizontal displacement was less in comparison with other materials. When the surcharge is applied, the increase in the percentage of crumb rubber or the decrease of the quantity of sand in the mixture of crumb rubbersand has led to the increase in the wall displacement, and the use of a $30 \%$ crumb rubber mixture compared to the other percentages has resulted in a more favorable performance.

Figure 13 shows the safety factor when different percentages of crumb rubber-sand were used for the two geogrids A and $\mathrm{B}$ compared to the other materials. The results show that the use of the $30 \%$ crumb rubber has a higher safety factor compared to the other percentages of crumb rubber. The tensile strength of geogrid B, when dense soils, sand-gravel mixture and $30 \%$ crumb rubber are used, is not significantly different from the tensile strength of geogrid A, and has involved the similar safety factor. The full scale pull out and direct shear tests for each geogrids A and B, performed by Tanchausawat et al., led to the different interaction coefficients.

In this section, the effect of different interactions for each reinforcement elements in the wall displacement and also safety factor are studied. With increased crumb rubber quantity, the difference between the two tests of pull out and direct shear for geogrid B would increase, and the safety factor is decreased. Also, the maximum settlement values for geogrids $\mathrm{B}$ (in the two test) and A are not so different. Generally, the use of the results obtained from the pull out test resulted in some confidence inclined coefficients (Fig. 14).

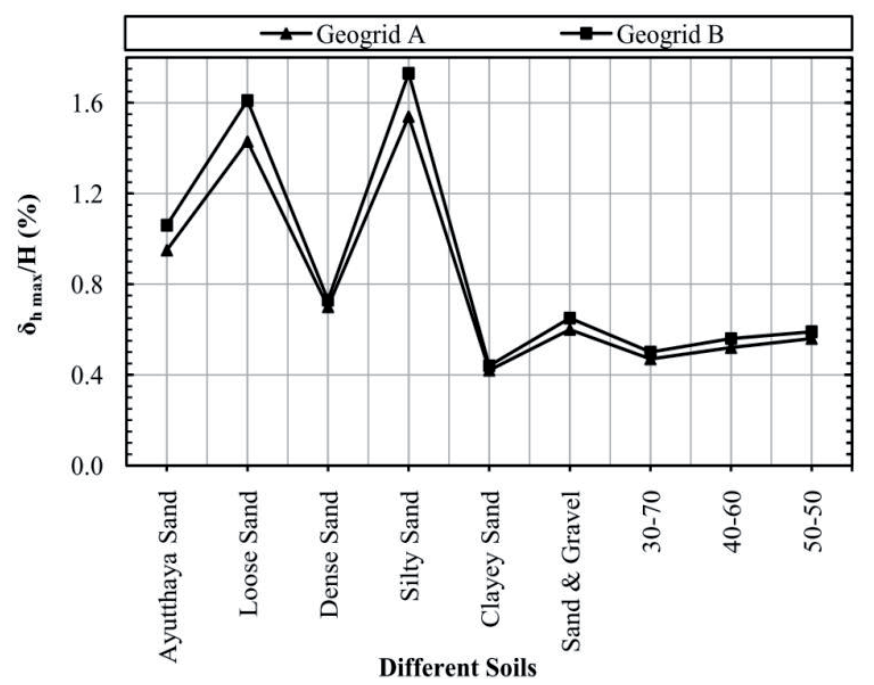

Fig. 7 Effect of tire chips-sand mixture in Horizontal Displacement

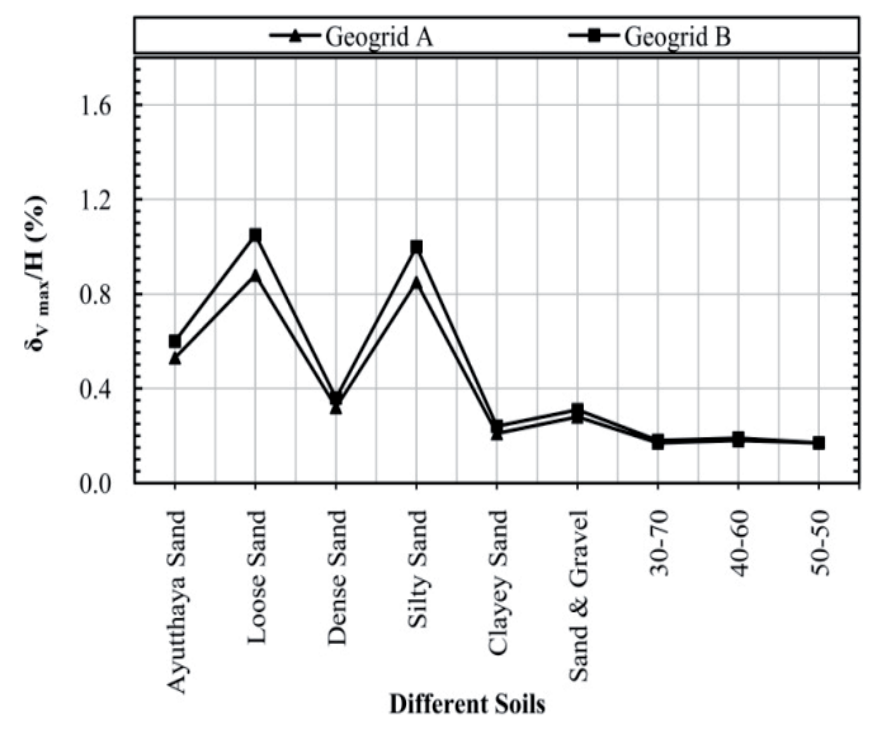

Fig. 8 Effect of tire chips-sand mixture in Vertical Displacement

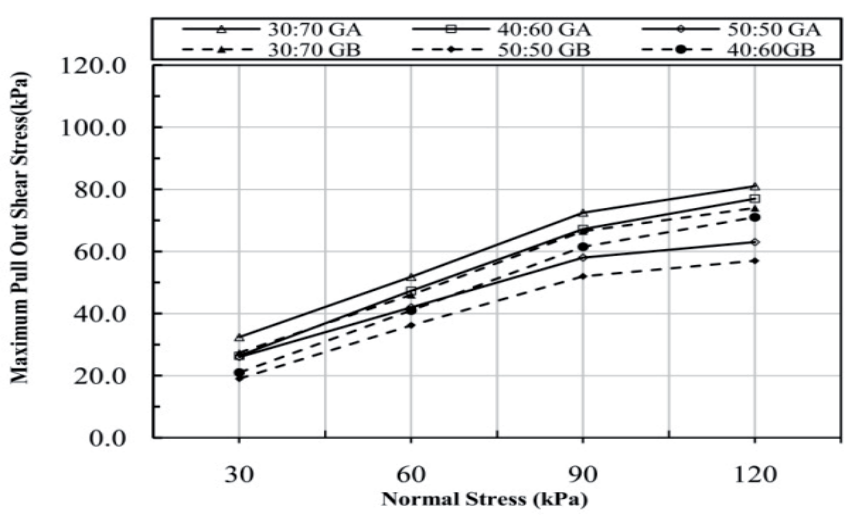

Fig. 9 Maximum pull out shear stress versus normal stress. Note: GA: Geogrid A \& GB:Geogrid B [13]

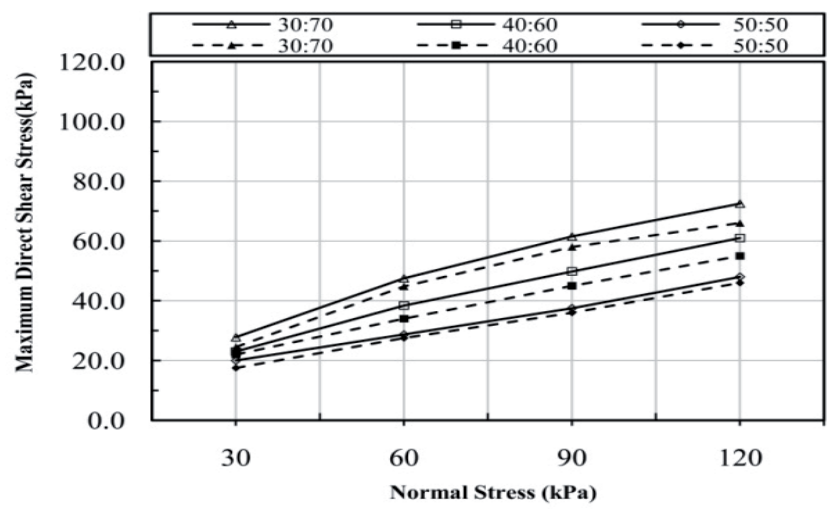

Fig. 10 Maximum direct shear stress versus normal stress [13]. Note: soild symbol $=$ with Geogrid B \& Hollow symbol $=$ with out Geogrid B 


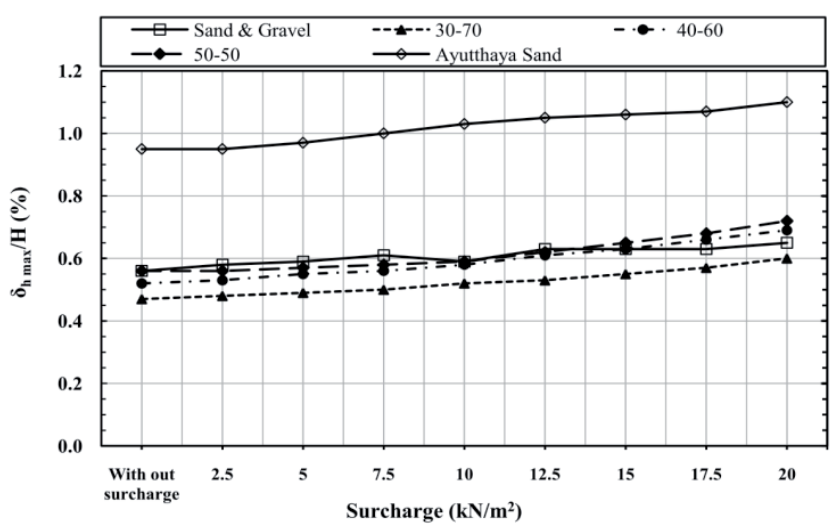

Fig. 11 Effect of tire chips-sand mixture in Horizontal Displacement with different surcharge.

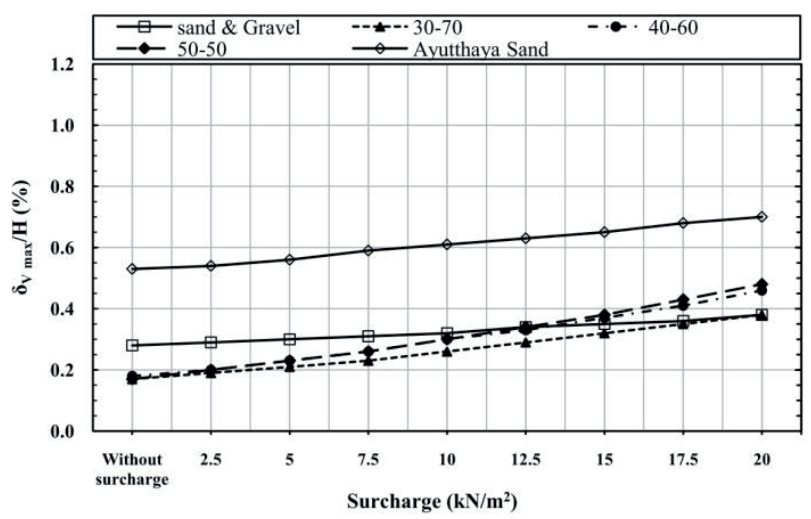

Fig. 12 Effect of tire chips-sand mixture in Vertical Displacement with different surcharge.

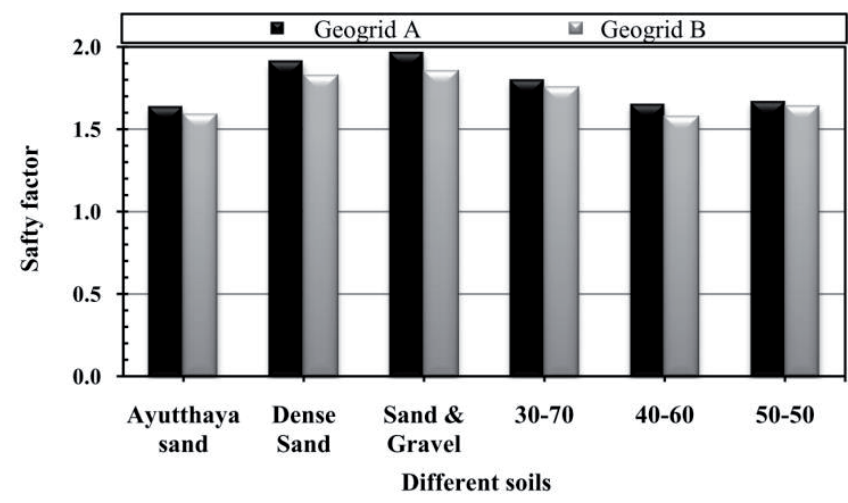

Fig. 13 Effect of tire chips-sand mixture in factor of safety.

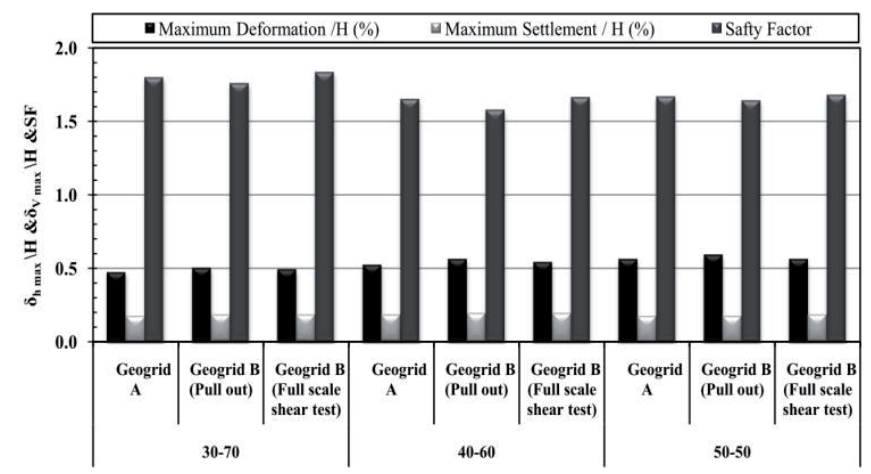

Fig. 14 Effect of interaction coefficient in performance of wall

\subsection{The effect of the backfill behind the wall with different percentages of crumb rubber in various layers}

In the back of the wall, usually one type of fill material is used in layers. In this paper, different backfill materials in layers with a height of $2.5 \mathrm{~m}$ were used. The purpose of this way is to investigate the effect of using different materials on the performance of geosynthetic reinforced earth walls. The studied models include 20 different types of backfills in layers with a height of $2.5 \mathrm{~m}$, and for each walls, 4 types of materials with different properties were used. Among the provided models, backfill 9 (E9) had the lowest displacement and settlement. The results show that while these types of materials were used, the difference in the geogrid tensile strength had no effect on the displacement and settlement, and the values for the two geogrids A and B have a conformity with each other. The use of three layers of crumb rubber-sand and one layer of sand and gravel resulted in a better performance compared to the other states. By placing a sand layer lacking crumb rubber in higher layers, the values for horizontal displacement and settlement were increased, and the most optimal state was when sand materials lacking crumb rubber were used in the first layer (Figs. 15 and 16).Among the models, only the backfill 3 (E3) model had a performance similar to the Ayutthaya sand, and all the studied models had a lower displacement compared to the Ayutthaya sand. Backfills 6, 5, 1 and 13 had an almost equal maximum displacement and when they were used, a similar performance was achieved with the use of clayey sand.

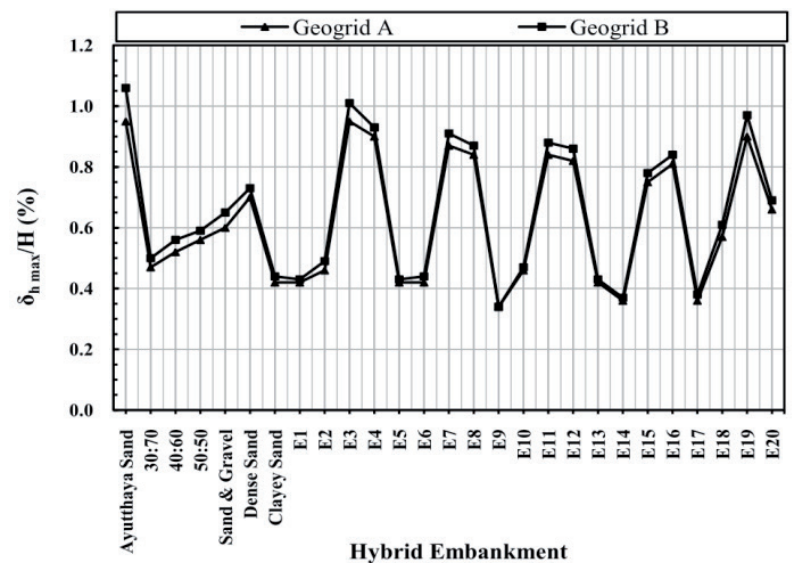

Fig. 15 Effect Use of backfill materials with different layers in Horizontal Displacement. 


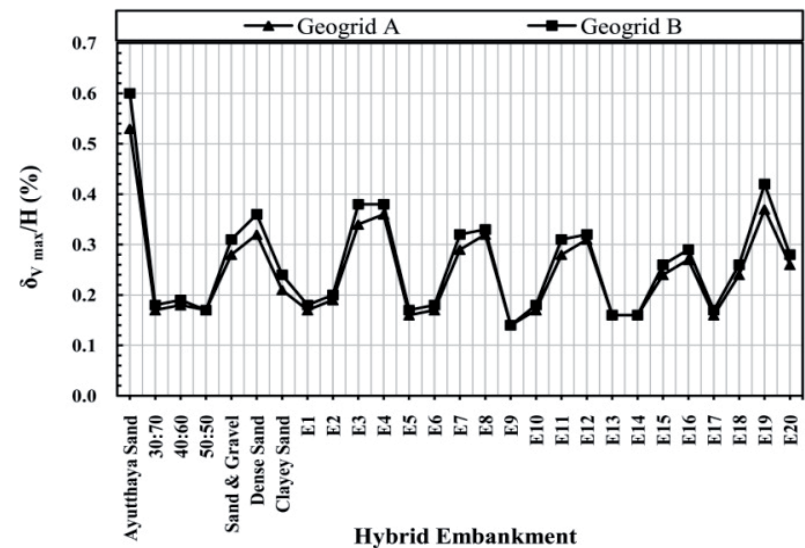

Fig. 16 Effect Use of backfill materials with different layers in Vertical Displacement.

Therefore, it's possible to use material combinations such as backfill 1 to cause a similar displacement compared to when clayey sand was used.

BackFills 9, 14 and 17 had the better performance compared to each fills. When this type of backfill was used, the geogrid tensile strength had no effect on the wall performance. For example, when backfill 9 was used, a horizontal displacement equaling almost 0.34 was obtained, whereas for the 30:70 crumb rubber-sand mixture, combination of sand and gravel, and clayey sand, the obtained displacements were $0.47,0.6$ and 0.42 , respectively (figure 15 and 16).

It seems that the use of sand and gravel one-layer in the primary level and the other crumb rubber-sand mixtures in the next levels (E9, Table 7) resulted in less horizontal and vertical displacement compared to when each aforementioned materials have been used (Figs. 15 and 16).

\subsection{The effect of crumb rubber with different maximum size}

In this part, crumb rubbers with different maximum sizes have been used in three layers with a height of $0.5 \mathrm{~m}$ (Fig. 5). In this regard, three different percentages of crumb rubber-sand have been used as backfill materials. The purpose of this part was to investigate the effect of using crumb rubber layers, the size of the crumb rubbers, the effect of the simultaneous use of crumb rubber and mixture of crumb rubber-sand. For this purpose, the properties of crumb rubbers with different maximum sizes resulting from various experimental studies of different researchers have been used.

Figures 17 and 18 show the values of wall horizontal displacement and settlement when three crumb rubbers with different sizes, sand fills, mixture of sand and crumb rubbers with different percentages are used. In these figures, it's observed that in a state in which crumb rubber layers are used, less horizontal settlement has been achieved. The increase in the percentage of crumb rubber in the mixture of crumb rubber-sand has resulted in the increase of wall's horizontal displacement for all the crumb rubber sizes. The use of a $30 \%$ mixture of crumb rubber-sand has led to a better performance.

When the mixture of crumb rubber-sand was used, the size of the crumb rubber-sand particles had a lower effect on the maximum horizontal displacement and by the mean, had a difference about $0.03 \%$. The particle sizes, when sand as the fill materials were used, had a higher effect on the maximum wall displacement.

The increase in the maximum of crumb rubber particles for all the fill materials including the mixture of crumb rubbersand and sand resulted in the decrease of the horizontal wall displacement. Figure 19 shows the effect of crumb rubber size and the percentage of crumb rubber with the use of the pull out test performed by Balunaini [14, 20]. According to the pull out test, the increase of the maximum particle size of crumb rubber resulted in the increase of the pull out capacity and decrease of the displacement. Of course, the point worth mentioning is that the particle size of the crumb rubber had a small effect.

The results of the pull out test show the increase of the particle size caused increasing pull out capacity, and in the wall studied in this paper, the increase of the particle size caused decreasing horizontal displacement and this result is a good agreement with the results of the pull out test. The simultaneous use of crumb rubber layers and crumb rubber-sand mixture for all the crumb rubber percentages had a very small effect on the maximum settlement. In the sand fill, the increase of the crumb rubber particles led to the increase of the settlement. Generally, the use of crumb rubber layers compared to the use of different materials lacking crumb rubber layers, resulted in maximum settlement increase (Fig.18).

Figure 20 shows the different materials used in the previous parts, which had a better performance compared to the other states. In comparison to all the states, the combined design of layers with a height of $2.5 \mathrm{~m}$ for the two fills of 9 and 14 resulted in the wall's best performance. The use of the 30:70 crumb rubber-sand mixture resulted in less displacement compared to the other percentages and backfills. The horizontal displacement resulted from the three crumb rubber layers, when the 30:70 crumb rubber-sand mixture was used, had the most desirable state in the previous part. The results show that the use of combined design of materials compared to the other states, caused less horizontal displacement, and also the design can become more economical. 


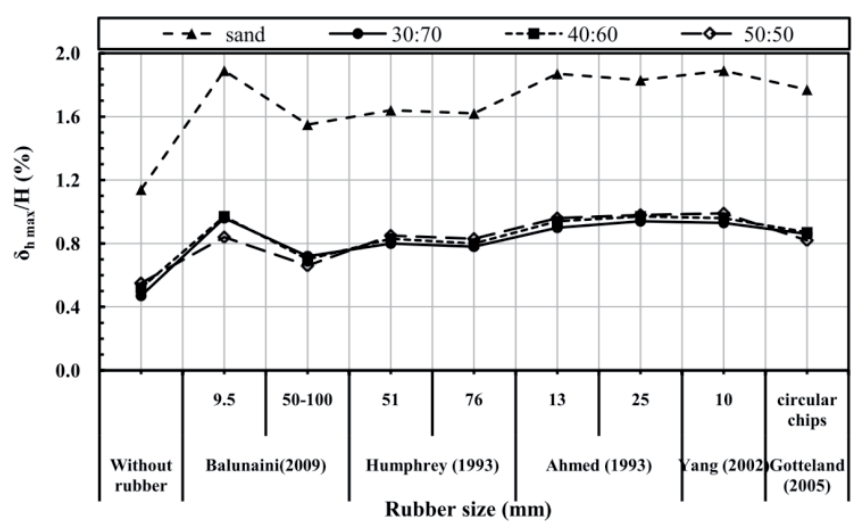

Fig. 17 Effect use of crumb rubber with different maximum size in Horizontal Displacement

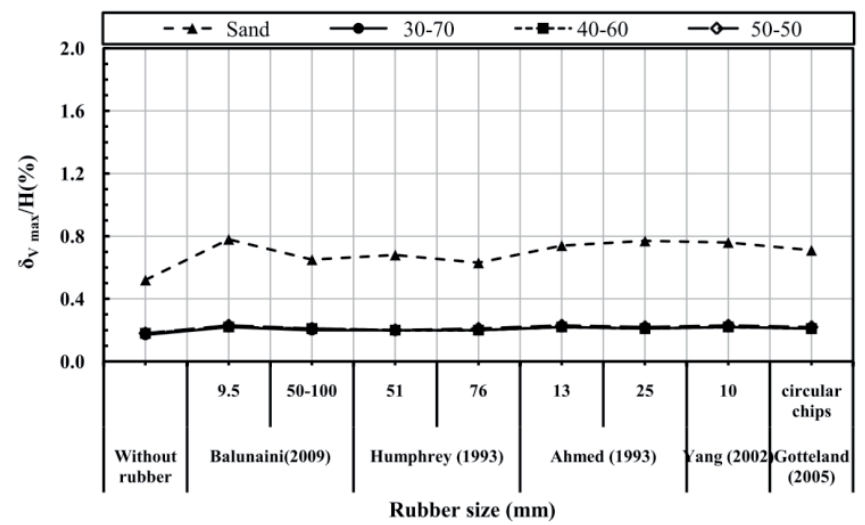

Fig. 18 Effect use of crumb rubber with different maximum size in Vertical Displacement.

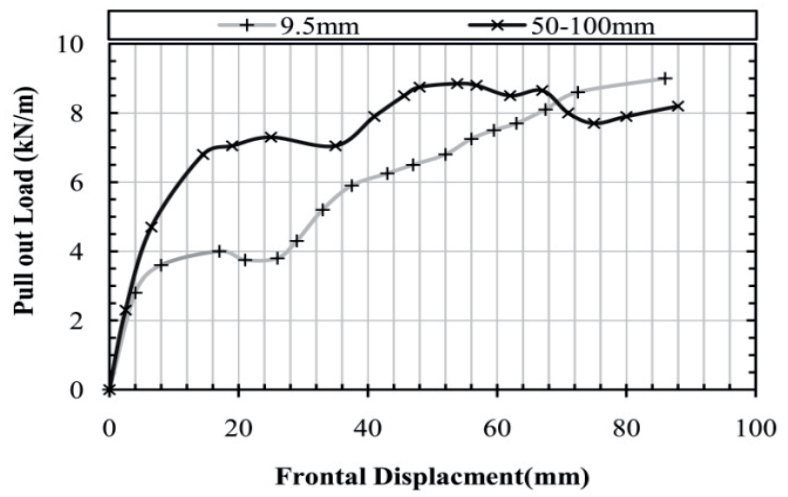

Fig. 19 Pull out the test results for crumb rubber size 9.5 and 50-100 $\mathrm{mm}$ [20].

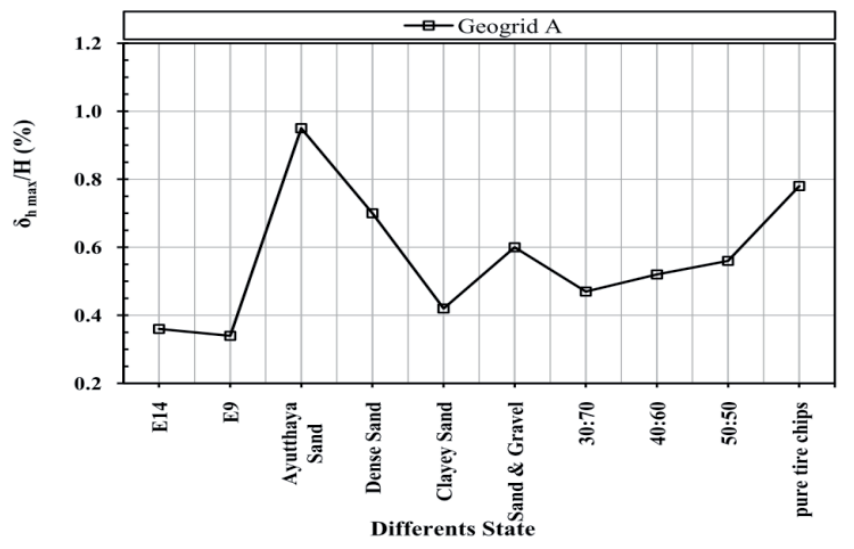

Fig. 20 Performance of earth wall for various materials.

\subsection{Use of crumb rubber in the foundation of wall}

In order to evaluate the effect of using crumb rubber-sand in wall foundation, layers with depths of 0.5 and $1 \mathrm{~m}$ (Fig. 6) with different percentages of crumb rubber-sand, have been used. The increase of the layer depth from 0.5 to $1 \mathrm{~m}$, when the crumb rubber-sand was used, has caused the maximum wall displacement and settlement increased. The geogrids strength had a higher effect when the quantity of crumb rubber-sand and depth was increased, and for the other states, their difference was almost constant (Figs. 21 and 22).

The increase of the percentage of crumb rubber in the mixture of crumb rubber-sand has caused an increase in the maximum horizontal and vertical displacement (settlement) for depths of 1 and $0.5 \mathrm{~m}$. Also, this effect was increased with the increases of depth. The use of different percentages of crumb rubber resulted in the increase of wall displacement in a way that for the main wall state and geogrid A, horizontal and vertical displacements about 0.66 and 0.32 , respectively, have been resulted, and when 1 meter layer was used in foundation, the values, were measured for the 30:70 compound, were 0.96 and 0.5 , respectively. Figure (23) shows the safety factors for geogrid A when 1 meter layer was used in the wall foundation with different combinations. The use of different combinations of crumb rubber-sand and other states results in reducing safety factor. The increase of the crumb rubber percentage from 30 to 50 decreased the safety factor from 1.53 to 1.291 .

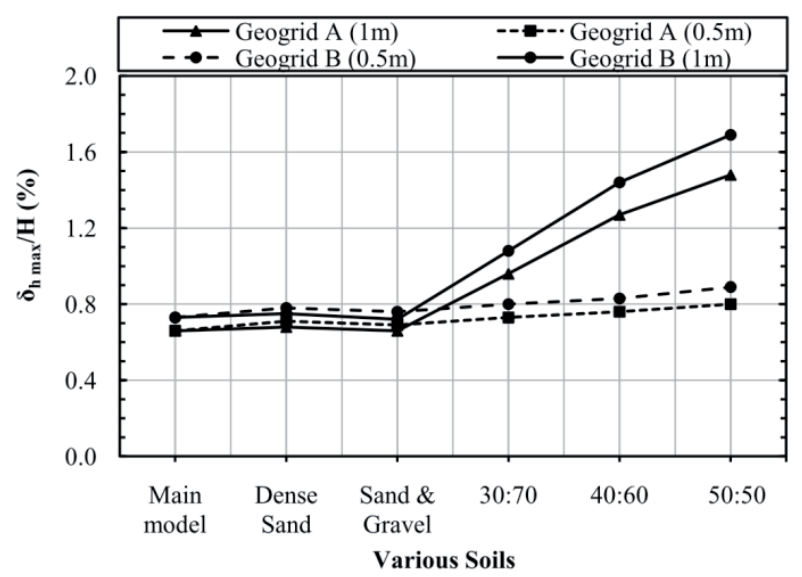

Fig. 21 Effect use of crumb rubber in the foundation of wall in Horizontal Displacement. 


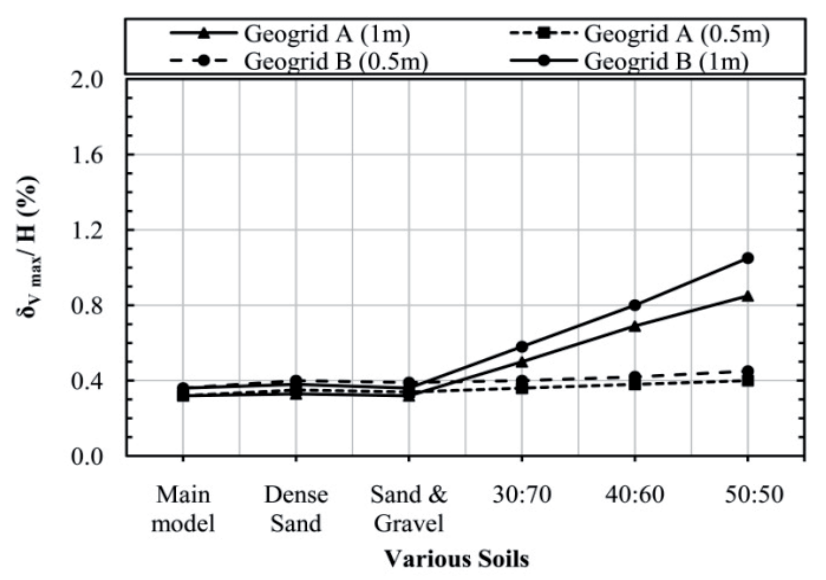

Fig. 22 Effect use of crumb rubber in the foundation of wall in Vertical Displacement.

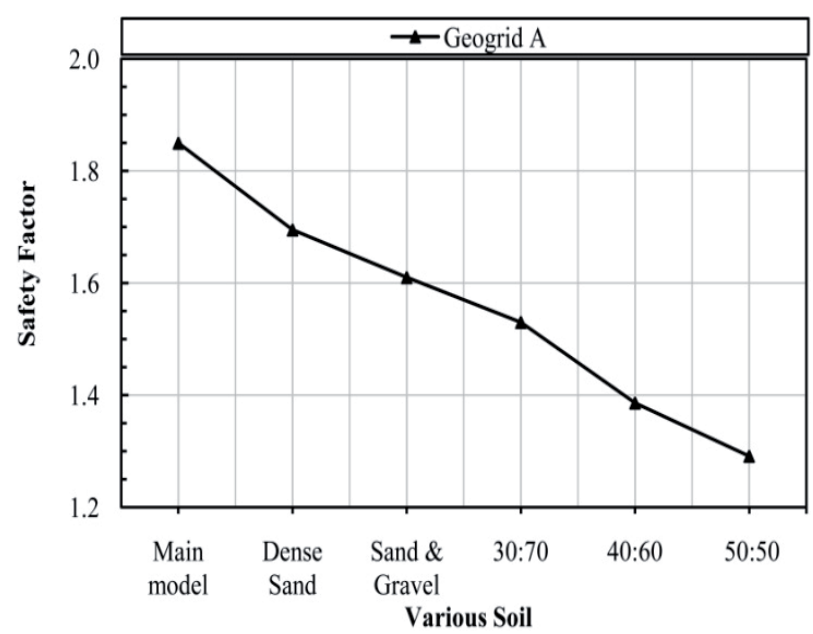

Fig. 23 Safety factor for use of different material in the foundation of wall

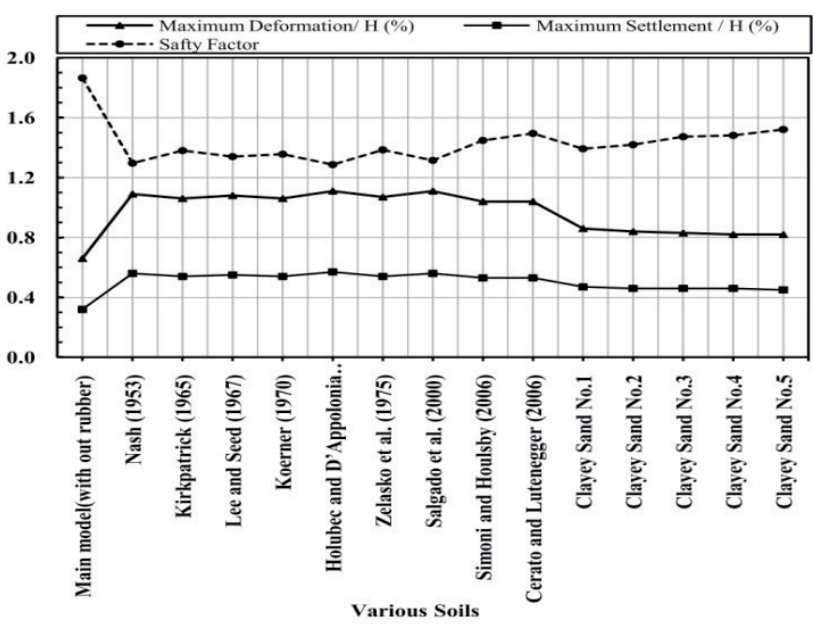

Fig. 24 Effect use of different soils in wall foundation

The use of the 1 meter layer in the wall foundation for the state in which, the most desirable materials are used, results in the decrease of the safety factor about 0.3 . Generally, the use of crumb rubber-sand in the foundation soil with different depths does not have a desirable effect on wall performance.
To evaluate the effect of different wall foundation soils when one replaced layer of crumb rubber materials was used, a $1 \mathrm{~m}$ layer replaced with the 30:70 compound of rubber-sand was used in the wall foundation. In this regard, 6 different types of granular soil, whose geotechnical properties have been reported by different researchers, and 5 soil types with different cohesion have been used. The increase of the angle of internal friction and cohesion decreases the wall horizontal displacement and also increases the safety factor. The increase in the internal friction angle and cohesion does not have much effect on the maximum settlement (Fig. 24). Generally, the use of crumb rubber in wall foundation for soils with higher internal friction angle and cohesion causes the better conditions for the wall performance.

\section{Conclusions}

This paper shows the performance of geogrid reinforced soil wall when different percentages of crumb rubber-sand and only crumb rubber are used. The results show that:

1. The increase in the percentage of crumb rubber when it's combined with sand increases maximum horizontal displacement, but does not really affect in the maximum settlement.

2. The mixture of 30:70 crumb rubber-sand resulted in a better performance in the wall. The tensile strength of the geogrids for sandy soils with high cohesion or density has less effect on the maximum horizontal displacement and this effect was significantly increased via the increase of the crumb rubber.

3. The compound design of back wall materials, when a sand layer is placed in the primary level and the other crumb rubber-sand mixtures are placed in higher levels, results in very good wall performance and higher safety factors compared to the cases in which, crumb rubbersand mixtures or sand materials have been used.

4. The use of crumb rubber-sand in the wall foundation caused increase of the maximum horizontal displacement and settlement, and the increase in the percentage of crumb rubber increased the changes the use of crumb rubber-sand in the wall foundation did not desirable affect on the wall performance.

5. The decrease of the quantity of sand in the mixture of crumb rubber-sand for the two states of post-construction and when different surcharge have been applied caused increase of wall displacement.

6. The use of crumb rubber-sand mixture resulted in the decrease of the effect of reinforcement elements' tensile strength.

7. Using materials in layers possibly decrease the wall horizontal displacement, increase the safety factor and also decrease the design cost. 
8. The increase in the maximum size of crumb rubber from 9.5 to $50-100 \mathrm{~mm}$ caused increase of pull out strength and also the decrease in the wall displacement.

9. Long-term behaviour of reinforced earth walls requires field measurements thus due to the different experimental study in this issue, the distribution of the horizontal displacement of the wall after the completion depends on facing and materials used in the wall. For relatively flexible wall facing material, displacement advances in the top layer, but in the case of relatively stiff wall facing material, arc shaped deformation with its peak close to the middle of the wall height appears and use of materials with less unit weight (such as chip tire sand mixture) caused less displacement.

10. Distributions of strain of the geogrids in long-term depends on different parameters such as wall facing, charactristics of back fill and etc. flexible wall facing, distributed in the shape of a parabola with its peak close to the active failure line, and if relatively stiff wall facing is done, its distribution is shaped like a triangle with its peak close to the wall facing. Use of scrap tire in reinforced earth wall caused increase in interaction between geogrid and materials and reduced the strain in geogrids.

\section{References}

[1] Humphrey, D. N., Nickels, W. L. "Effect of tire chips as lightweight fill on pavement performance.” In: Proc. 14th Int. Conf. on Soil Mechanics and Foundation Engineering, New Delhi, India, pp. 1617-1620. 1997.

[2] Lee, J. H., Salgado, R., Bernal, A., Lovell, C. W. "Shredded tires and rubber-sand as lightweight backfill." Journal of Geotechnical and Geoenvironmental Engineering. 125 (2), pp. 132-141. 1999. DOI: 10.1061/ (ASCE)1090-0241(1999)125:2(132)

[3] Salgado, R., Yoon, S., Siddiki, N. Z. "Construction of tire shred test embankment." Technical Rep. PFHWA/IN/JTRP-2002/35. Joint Transportation Research Program, Indiana Department of Transportation and Purdue University, West Lafayette, Indiana. 2003. DOI: 10.5703/1288284313165

[4] O’Shaughnessy, V., Garga, V. K. "Tire-reinforced earthfill. Part 2: Pullout behavior and reinforced slope design." Canadian Geotechnical Journal. 37 (1), pp. 97-116. 2000. DOI: 10.1139/t99-085

[5] Foose, G. J., Benson, C. H., Bosscher, P. J. "Sand Reinforced with Shredded Waste Tires." Journal of Geotechnical Engineering (ASCE). 122 (9), pp. 760-767. 1996. DOI: 10.1061/(ASCE)0733-9410(1996)122:9(760)

[6] Yoon, Y. W., Cheon, S. H., Kang, D. "Bearing capacity and settlement of tire-reinforced sands." Geotextiles and Geomembranes. 22 (5), pp. 439453. 2004. DOI: 10.1016/j.geotexmem.2003.12.002

[7] Youwai, S., Bergado, D. T. "Numerical analysis reinforced wall using rubber tire chips-sand mixtures as backfill material." Computers and Geotechnics. 31 (2), pp. 103-114. 2004. DOI: 10.1016/j.compgeo.2004.01.008

[8] Gotteland, P., Lambert, S., Balachovski, L. "Strength characteristics of tyre chips-sand mixtures." Studia Geotechnica et Mechanica. 27 (1-2), pp. 55-66. 2005. http://www.sgem.pwr.edu.pl/iss/2005/no12/art06_ no12 2005.pdf
[9] Hataf N., Rahimi, M. M. "Experimental investigation of bearing capacity of sand reinforced with randomly distributed tire shreds." Construction and Building Materials. 20 (10), pp. 910-916. 2006. DOI: 10.1016/j.conbuildmat.2005.06.019

[10] Attom, M. F. “The Use of Shredded Waste Tires to Improve the Geotechnical Engineering Properties of Sands.” Environmental Geology. 49 (4), pp. 497-503. 2006. DOI: 10.1007/s00254-005-0003-5

[11] Ghazavi, M., Sakhi, M. "Influence of Optimized Tire Shreds on Shear Strength Parameters of Sand." International Journal of Geomechanics. 5 (1), pp. 58-65. 2005. DOI: 10.1061/(ASCE)1532-3641(2005)5:1(58)

[12] Prasad, D. S. V., Raju, G. V. R. "Performance of waste tyre rubber on model flexible pavement." ARPN Journal of Engineering and Applied Sciences. 4 (6), pp. 89-92. 2009. http://www.arpnjournals.com/jeas/research_papers/rp_2009/jeas_0809_232.pdf

[13] Tanchaisawat, T., Bergado, D. T., Voottipruex, P., Shehzad, K. "Interaction between geogrid reinforcement and tire chip-sand lightweight backfill." Geotextiles and Geomembranes. 28 (1), pp. 119-127. 2010. DOI: 10.1016/j.geotexmem.2009.07.002

[14] Balunaini, U., Prezzi, M. "Interaction of Ribbed-Metal-Strip Reinforcement with Tire Shred-Sand Mixtures." Geotechnical and Geological Engineering. 28 (2), pp. 147-163. 2010. DOI: 10.1007/s10706-009-9288-6

[15] Marandi, S. M., "Reducing the forces caused by earthquake on Retaining walls using granulated rubber-soil Mixture." International Journal of Engineering, B Applications. 24 (4), pp. 337-350. 2011. http://www.ije.ir/ abstract/\%7BVolume:24-Transactions:B-Number:4\%7D/=1151

[16] PLAXIS. "PLAXIS version 8.2.” Reference manual, 2005.

[17] Wongsawanon, T. "Interaction between hexagonal wire mesh reinforcement and silty sand backfill." M. Eng. Thesis No. GE-97-14, Asian Institute of Technology, Bangkok, Thailand. 1998.

[18] Supawiwat, N. "Behavior of shredded rubber tires with and without sand, its interaction with hexagonal wire reinforcement and their numerical simulation.” M. Eng. thesis No. GE-01-14, Asian Institute of Technology, Thailand. 2002.

[19] ASTM International. "ASTM D6270-98 - Standard practice of use scrap tires in civil engineering applications." 1998.

[20] Balunaini, U., Yoon, S., Prezzi, M., Salgado, R. “Tire Shred Backfill in Mechanically Stabilized Earth Wall Applications." JTRP Technical Reports, 172 p. Purdue University Press, West Lafayette. 2009. http:// www.amazon.in/Shred-Backfill-Mechanically-Stabilized-Applications/ $\mathrm{dp} / 1622600975$

[21] Elias, V., Christopher, B. R., Berg, R. R. "Mechanically stabilized earth walls and reinforced soil slopes, design and construction guidelines." Technical Report, Publication No. FHWA-NHI-00-043, Federal Highway Administration (FHWA), Washington (DC). 2001. http://isddc.dot.gov/ OLPFiles/FHWA/010567.pdf

[22] Bergado, D. T., Youwai, S., Teerawattanasuk, C., Visudmedanukul, P. "The interaction mechanism and behavior of hexagonal wire mesh reinforced embankment with silty sand backfill on soft clay." Computers and Geotechnics. 30 (6), pp. 517-534. 2003. DOI: 10.1016/S0266352X(03)00054-5

[23] Bareither, C. A., Edil, T. B., Benson, C. H., Mickelson, D. M. "Geological and Physical factors affecting the friction angle of compacted sands." Journal of Geotechnical and Geoenvironmental Engineering. 134 (10), pp. 1476-1489. 2008. DOI: 10.1061/(ASCE)1090-0241(2008)134:10(1476)

[24] Maryland Department of the Environment's Scrap Tire Program. "Guidance maunal For Engineering Uses of Scrap Tires.” Geosyntec Project No.: ME0012-11. 2008. http://www.mde.state.md.us/assets/document/ Guidance_Manual_For_Scrap_Tires.pdf 
[25] Edeskär, T. "Technical and Environmental Properties of Tire Shreds Focusing on Ground Engineering Applications." Technical Report, Department of Soil Mechanics and Foundation Engineering Division of Structural Engineering, 2004. http://epubl.ltu.se/1402-1536/2004/05/index-en. html

[26] Masad, E., Taha, R., Ho, C., Papagionnakis, T. "Engineering properties of tire/rubber mixtures as a lightweight fill material." Geotechnical Testing Journal. 19 (3), pp. 297-304. 1996. DOI: 10.1520/GTJ10355J

[27] Gebhardt, M. A. "Shear strength of shredded tires as applied to the design and construction of a shredded tire stream crossing." M. Sc. thesis, Iowa State University, Ames, Iowa. 1997. http://lib.dr.iastate.edu/cgi/viewcontent.cgi?article $=17997 \&$ context $=$ rtd

[28] Wu, W. Y., Benda, C. C., Cauley, R. F. "Triaxial determination of shear strength of tire chips." Journal of Geotechnical and Geoenvironmental Engineering. 123 (5), pp. 479-482. 1997. DOI: 10.1061/(ASCE)10900241(1997)123:5(479)
[29] Zheng-Yi, F., Sutter, K. G. "Dynamic properties of granulated rubber/ sand mixtures." Geotechnical Testing Journal. 23 (3), (2000), 338-344. 2000. https://trid.trb.org/view.aspx?id=668922

[30] Zornberg, J. G., Cabral, A. R., Viratjandr, C. "Behaviour of tire shredsand mixtures." Canadian Geotechnical Journal. 41 (2), pp. 227-241. 2004. DOI: $10.1139 / \mathrm{t} 03-086$

[31] Ahmed, I. „Laboratory Study on Properties of Rubber-Soils.” Purdue University, Indiana, Joint Highway Research Project, Report No. FHWA/IN/JHRP-93/4. 1993. http://docs.lib.purdue.edu/cgi/viewcontent. cgi?article $=2547 \&$ context $=$ jtrp

[32] Yang, S., Lohnes, R. A., Kjartanson, B. H. „Mechanical Properties of Shredded Tires." Geotechnical Testing Journal. 25 (1), pp. 44-52. 2002. DOI: 10.1520/GTJ11078J

[33] Association of Swiss Road and Traffic Engineers. „Characteristic Coefficients of soils." Swiss Standard SN 670 010b. 1999. 